Pak. j. sci. ind. res. Ser. B: biol. sci. 2014 57(2) 97-103

\title{
Acute Toxicity of Water Soluble Fraction of Crude Oil to the Early Life Stages of the African Catfish (Clarias gariepinus)
}

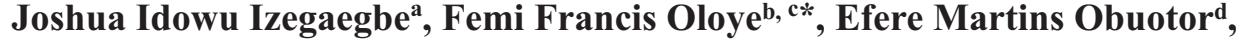 \\ Victor Funso Olaleye ${ }^{\mathrm{e}}$ and Stephen Adeyeni ${ }^{\mathrm{e}}$ \\ ${ }^{a}$ Department of Zoology, Ambrose Alli University, Ekpoma, Nigeria \\ ${ }^{b}$ Department of Chemistry, Adekunle Ajasin University, Nigeria \\ 'Department of Chemistry, Obafemi Awolowo University, Ile-Ife, Nigeria

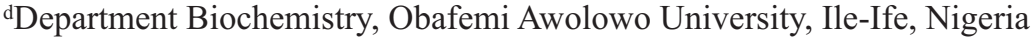 \\ e Department of Zoology, Obafemi Awolowo University, Ile-Ife, Nigeria
}

(received December 28, 2012; revised September 23, 2013; accepted October 14, 2013)

\begin{abstract}
Acute toxicity bioassay of water soluble fraction of crude oil (Escravos blend), was conducted to evaluate the toxicity on the early life stages of the African catfish (Clarias gariepinus) under static bioassay conditions. Five concentrations of water soluble fraction (WSF) of the crude oil $(0,1.25,2.5,5$, 10 and $20 \%)$ were constituted in glass aquaria $(25 \mathrm{~cm} \times 24 \mathrm{~cm} \times 10 \mathrm{~cm})$. Twenty laboratory-reared frys were introduced in triplicate in each of the test aquaria and exposure conducted for $96 \mathrm{~h}$. The median lethal concentration $\left(\mathrm{LC}_{50}\right)$ and the $95 \%$ confidence interval was estimated using Trimmed Spearman-Karber method. The physicochemical characteristic of the test media was also evaluated. The $96 \mathrm{~h}$ median lethal concentration $\left(\mathrm{LC}_{50}\right)$ at $95 \%$ confidence interval was estimated to give $2.84 \%$ (upper and lower confidence interval of $3.83 \%$ and $2.10 \%$ ) of the water soluble fraction. There was no marked change in $\mathrm{pH}$ of the test media compared to the control. However, the dissolved oxygen content and the conductivity showed a concentration dependent decline in the test media when compared to the control. The frys were observed to be weak and swimming activities were reduced. It can be concluded from the study that the water soluble fraction of crude oil (Escravos blend) is toxic to early life stages of C. gariepinus.
\end{abstract}

Keywords: crude oil, Clarias gariepinus, water soluble fraction, toxicity

\section{Introduction}

The level of a country's activity in petroleum refining and petrochemical businesses is desirable for her National development and economic growth. However, every stage in the petrochemical process (exploration, drilling, extraction, transport, refining and combustion) can have potential harmful effects on human and environmental health (Epstein and Selber, 2002). The effects of petroleum exploration and production activities on the Nigerian environment have been the cause of great concern in recent times especially in the Niger delta, where over 550 reported cases of crude oil spillages have occurred since 1976. The serious environmental effects of some oil spill, have served to make government, industry and public aware of possible risk associated with the petrochemical process (Murray, 1984). Documented reports showed that about 2.8 million barrels of oil had been spilled into the Niger delta environment alone (Ojediran and Ndibe, 2005). Changes in environmental quality can therefore, be a major concern of year-class strength and eventually the long-term

*Author for correspondence; E-mail: pen2crown@gmail.com dynamics of many fish populations (Rose et al., 1993). Varieties of pollutants including crude oil are known to induce stress conditions which impair the health of fish (FEPA, 1991). Frequent crude oil spillages and its products have resulted in a marked reduction in the fish populations in the creeks and creeklets of the Niger delta (Ekweozor, 1989). The aquatic environment, where fish and other aquatic organisms live, is subjected to different types of pollutants, which enter water bodies through industrial, domestic and agricultural discharge systems thereby introducing stress to living creatures. Stress is a general and non-specific response to any factors disturbing homeostasis. Stress reaction involves various physiological changes including alteration in blood composition and immune mechanisms (Witeska, 2003; Svoboda, 2001). The most serious problem for aquatic life appears to arise from that portion of the oil, which is soluble in water-the water soluble fraction (WSF) (Murray, 1984). The effects of water soluble fraction have been reported on Oreochromis niloticus (Dede and Kaglo, 2001) and Metamysidopsis insularis (Mohammad, 2005). Stress in fish may be induced by 
various abiotic environmental factors (changes in water temperature, $\mathrm{pH}, \mathrm{O}_{2}$ concentration and pollution). Although this fraction is present only in relatively low concentrations, but it is the most intimate contact with fish and other pelagic organisms (Murray, 1984). Anderson (1977) has reported that behaviour is among the most sensitive and meaningful parameters in the study of pollutants effects. The present study, has been undertaken to evaluate the acute toxicity of water soluble fractions of crude oil to the early life stages of the African catfish (Clarias gariepinus). C. gariepinus was chosen because it is most widely cultivated in Nigeria (high commercial value), its ability to withstand stress and tolerate well and poorly oxygenated waters (hardy in nature) and hence used as biological indicator of ecotoxicological studies. It has also been used by others for ecotoxicity studies (Ololade and Oginni, 2010). The concept of using WSF in toxicity studies has been developed by many authors (Murray, 1984). This study is especially pertinent because of the near regularity of contamination of aquatic environment most especially during crude oil prospecting and production. Allen (1995) believes that stress in fish is a major factor of disease out breaks, low productivity, decreased growth, reduced mobility and mortality in aquaculture therefore, research initiated on fish most especially for $C$. gariepinus. Thus, detailed knowledge of fish (C. gariepinus) response to various stresses will be of greater help in improving production of fish and in providing information on ways of effectively controlling and monitoring stress in aqua-culture (Ololade and Oginni, 2010).

\section{Materials and Methods}

One kilogram $(1 \mathrm{~kg})$ female and $1.2 \mathrm{~kg}$ male $C$. gariepinus brood stocks purchased from a fish farm in Ota, Ogun State, Nigeria, were brought to the laboratory for artificial induction. One thousand (1000) hatchlings subsequently obtained from the fertilised eggs and were acclimatised in the laboratory for three weeks and fed ad libitum with Artemia salina prior to the start of the acute toxicity testing experiment.

Preparation of water soluble fraction. Water soluble fractions (WSF) were prepared following the procedure of Afolabi et al. (1985), using $200 \mathrm{~mL}$ of crude oil (Escravos blend) into $800 \mathrm{~mL}$ of doubled distilled water in a $1000 \mathrm{~mL}$ borosilicate screw capped conical flask. The crude oil and water mixture was shaken and stirred slowly using a Gallenkamp magnetic stirrer for $24 \mathrm{~h}$ to enhance the dissolution in the water of the water soluble components of the crude oil. After $24 \mathrm{~h}$ of shaking, the mixture was allowed to stand for a minimum of $3 \mathrm{~h}$ after which, it was poured into a separating funnel and allowed to stand overnight, to obtain a clear oil-water interphase. The lower layer of water containing the WSF of the crude oil, was decanted and then siphoned into dark coloured screw-capped Winchester bottle. The process was repeated several times until sufficient quantity of WSF was obtained to carry out the study. The WSF was measured out as $0,1.2,2.5,5.0,7.5$ and $10 \%$ and each concentration was made up to 1000 litre by adding doubled distilled water. These represented $0,12,25,50,75$ and 100 parts per million (ppm), respectively. The WSF concentrations were chosen to attempt to bracket different quantities that were lethal after different time periods (Busdosh, 1981).

Exposure of test organisms. The WSF were made into five different dilutions (concentrations) i.e., 1.25, 2.5, 5,10 and $20 \%$ with dechlorinated water in which the fish frys were reared. Twenty (20) frys per group were then exposed to five test tanks, in triplicates, each with a different concentration of the toxicant (WSF of crude oil) and a control tank (with no WSF of crude oil). The frys were observed for duration of $96 \mathrm{~h}$ in the exposure tanks and dead fish were removed at 4-8 $\mathrm{h}$ interval during the first $24 \mathrm{~h}$ of the test and subsequently 6-12 $\mathrm{h}$ interval during the next $72 \mathrm{~h}$ (Fish considered dead if they were immobile and made no respiratory movements).

$\mathbf{L C}_{50}$ determination. The numbers of dead fish per group were recorded in a tabular form as specified by Sprague (1973). The data obtained was used to calculate the median lethal concentration $\left(\mathrm{LC}_{50}\right)$ at $95 \%$ confidence intervals using Trimmed Spearman-Karber method.

Selected physicochemical parameters. The selected physicochemical parameters of the WSF of crude oil measured in this study were $\mathrm{pH}$, temperature, dissolved oxygen content and conductivity. The $\mathrm{pH}$ was measured using a LaMotte Analog $\mathrm{pH}$ meter, temperature was measured using mercury in glass thermometer, the dissolved oxygen content was determined using Winkler's titrimetric method (APHA, 1992), while conductivity was measured using a Jenway conductivity meter (E 512).

\section{Results and Discussion}

Trend in mortality. Within $24 \mathrm{~h}$ of exposure, hatchling mortality occurred in some exposure tanks. No mortality 
was recorded in the control tank and exposure tank containing $1.25 \%$ water soluble fraction (WSF). In the exposure tank with $2.5 \%$ concentration of WSF, the percentage mortality recorded was $10 \%$. While with $5 \%$ of WSF introduction in exposure tank, the percentage mortality recorded was $15 \%$. Exposure tank containing $10 \%$ WSF had $20 \%$ hatchling mortality, while mortality in exposure tank containing $20 \%$ concentration of WSF, recorded was $35 \%$. (Table 1 ).

Table 1. Toxicity testing of WSF of crude oil for the 96 h exposure in C. gariepinus

\begin{tabular}{|c|c|c|c|c|c|}
\hline $\begin{array}{l}\text { Duration of } \\
\text { exposure } \\
\text { (h) }\end{array}$ & $\begin{array}{l}\text { Concen- } \\
\text { tration } \\
(\%)\end{array}$ & $\begin{array}{l}\text { No. of } \\
\text { test } \\
\text { organism }\end{array}$ & $\begin{array}{l}\text { No. of } \\
\text { mortality }\end{array}$ & $\begin{array}{l}\text { Mortality } \\
(\%)\end{array}$ & $\begin{array}{l}\text { Average } \\
\text { mort./ } \\
\text { tank }\end{array}$ \\
\hline \multirow[t]{6}{*}{24} & 0.00 & 60 & - & - & - \\
\hline & 1.25 & 60 & - & - & - \\
\hline & 2.50 & 60 & 6 & 10 & 2 \\
\hline & 5.00 & 60 & 9 & 15 & 3 \\
\hline & 10.00 & 60 & 12 & 20 & 4 \\
\hline & 20.00 & 60 & 21 & 35 & 7 \\
\hline \multirow[t]{6}{*}{48} & 0.00 & 60 & - & - & - \\
\hline & 1.25 & 60 & 9 & 15 & 3 \\
\hline & 2.50 & 60 & 15 & 25 & 5 \\
\hline & 5.00 & 60 & 15 & 25 & 5 \\
\hline & 10.00 & 60 & 27 & 45 & 9 \\
\hline & 20.00 & 60 & 39 & 65 & 13 \\
\hline \multirow[t]{6}{*}{72} & 0.00 & 60 & - & - & - \\
\hline & 1.25 & 60 & 14 & 23.3 & 4 \\
\hline & 2.50 & 60 & 24 & 40 & 8 \\
\hline & 5.00 & 60 & 36 & 60 & 12 \\
\hline & 10.00 & 60 & 40 & 66.7 & 13 \\
\hline & 20.00 & 60 & 51 & 85 & 17 \\
\hline \multirow[t]{6}{*}{96} & 0.00 & 60 & - & - & - \\
\hline & 1.25 & 60 & 18 & 30 & 6 \\
\hline & 2.50 & 60 & 27 & 45 & 9 \\
\hline & 5.00 & 60 & 40 & 66.7 & 14 \\
\hline & 10.00 & 60 & 45 & 75 & 15 \\
\hline & 20.00 & 60 & 56 & 93.3 & 19 \\
\hline
\end{tabular}

After $48 \mathrm{~h}$ exposure, no mortality was recorded in the control tank. In exposure tank with $1.25 \%$ WSF, the percentage mortality was $15 \%$. In exposure tank with $2.5 \%$ concentration of WSF, the percentage mortality recorded was $25 \%$. With $5 \%$ WSF contamination, the percentage mortality recorded was $25 \%$. In exposure tank containing $10 \% \mathrm{WSF}$, the percentage mortality was $45 \%$, while in tanks with $20 \%$ concentration of WSF, the percentage mortality in C. gariepinus hatchlings was $65 \%$.

After $72 \mathrm{~h}$ exposure, no mortality was recorded in the control tank. However, in exposure tank containing
$1.25 \% \mathrm{WSF}$, the percentage mortality recorded was $23.3 \%$, while $40 \%$ hatchlings mortality was recorded in exposure tank with $2.5 \%$ concentration of WSF. Presence of 5\% WSF in the exposure tank led to $60 \%$ mortality after $72 \mathrm{~h}$ of exposure (Table 1). Presence of $10 \% \mathrm{WSF}$ in the exposure tank for $72 \mathrm{~h}$ also caused percentage mortality to rise to $66.7 \%$. While mortality recorded also rose to $85 \%$ in the medium containing $20 \%$ WSF after $72 \mathrm{~h}$ of exposure.

After $96 \mathrm{~h}$ exposure, no mortality was recorded in the control tank without WSF. The percentage mortality was $30 \%$ in exposure tank containing $1.25 \%$ WSF. In exposure tank with $2.5 \%$ concentration of WSF, the percentage $C$. gariepinus hatchling mortality recorded was $45 \%$, while for exposure tank containing of $5 \%$ of WSF, the percentage hatchling mortality recorded was $66.7 \%$. Similarly, in exposure tank containing $10 \%$ WSF, the percentage mortality was $75 \%$. After $96 \mathrm{~h}$ of exposure, the percentage mortality recorded was $93.3 \%$ when the exposure tank contained $20 \%$ concentration of WSF.

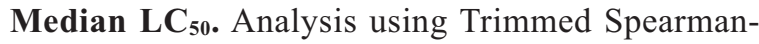
Karber method showed that the median $\mathrm{LC}_{50}$ value was 2.84 at $95 \%$ confidence interval (upper and lower confidence of 3.83 and 2.10) (Table 2).

Table 2. Median $\mathrm{LC}_{50}$ for ecotoxicology tests in C. gariepinus based on Trimmed Spearman-Karber

\begin{tabular}{lll}
\hline \hline Concentration (\%) & Number exposed & Mortality \\
\hline 0 & 60 & 0 \\
1.25 & 60 & 18 \\
2.5 & 60 & 27 \\
5.0 & 60 & 40 \\
10 & 60 & 45 \\
20 & 60 & 56 \\
\hline \hline
\end{tabular}

Spearman-Karber Trim: 30\%; Spearman-Karber Estimate: $\mathrm{LC}_{50}: 2.84 ; 95 \%$ lower confidence: $2.10 ; 95 \%$ upper confidence: 3.83 .

Physicochemistry of water soluble fraction. At the end of 96 h toxicity testing, the mean dissolved oxygen content of the exposure water is shown in Fig. 1. The results showed that the highest amount of dissolved oxygen (DO) $(7.3 \mathrm{mg} / \mathrm{L})$ was recorded in the exposure tank containing $1.25 \%$ of WSF crude oil. While the least dissolved oxygen $(4.6 \mathrm{mg} / \mathrm{L})$ was recorded in the exposure tank with $20 \%$ WSF of crude oil. The level 
of dissolved oxygen recorded in the control tank (without WSF), which was $6.8 \mathrm{mg} / \mathrm{L}$ was higher than the level of dissolved oxygen recorded in exposure tanks which had WSF of more than $2.50 \%$.

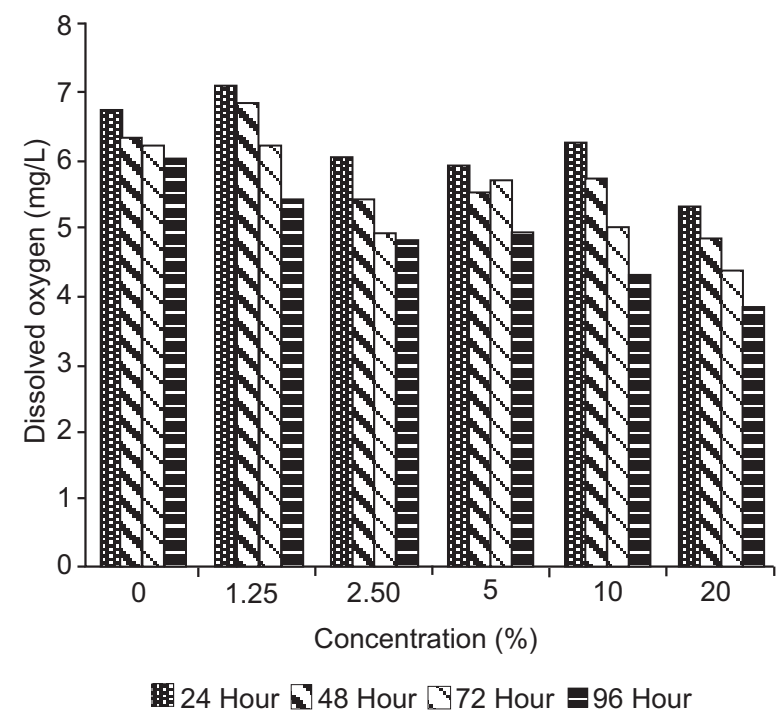

Fig. 1. Dissolved oxygen levels in test solutions during the acute toxicity in C. gariepinus.

Ololade and Ogini (2010) in their work concluded that short term exposure to high levels of toxicant induced stress reaction in fish and those gradual changes at lower concentration of toxicants in fish behaviour reflected a transient stress induced osmotic imbalance. This finally leads to reduction in the immune potential of fish and increases mortality rate at higher concentration. The oxygen stress encountered by the fish is due to their inability to withstand the oxygen depletion of the water induced by the organic compounds in WSF. C. gariepinus is capable of tolerating long periods of adverse conditions particularly low concentrations of dissolved oxygen, however, in order to reduce stress induced by DO, DO was maintained at 5.3-6.8 using oxygen pumps.

The water soluble fraction has been described as the small dissolved fraction which is available and may be toxic to the living organisms in aquatic environment. The most immediate toxic fractions of oil are those that are somewhat soluble in water (Hufford, 1971).

Hydrocarbons present in crude oil are toxic to many organisms especially those at early life stages (Lee et al., 2011).
The mean $\mathrm{pH}$ values of the culture water in the tank are shown in Fig. 2. The results showed that the highest amount of $\mathrm{pH}$ (7.9) was recorded in the exposure tank containing $20 \%$ of WSF crude oil. While the least $\mathrm{pH}$ was recorded in the exposure tanks with $1.25 \%$ and $5 \%$.

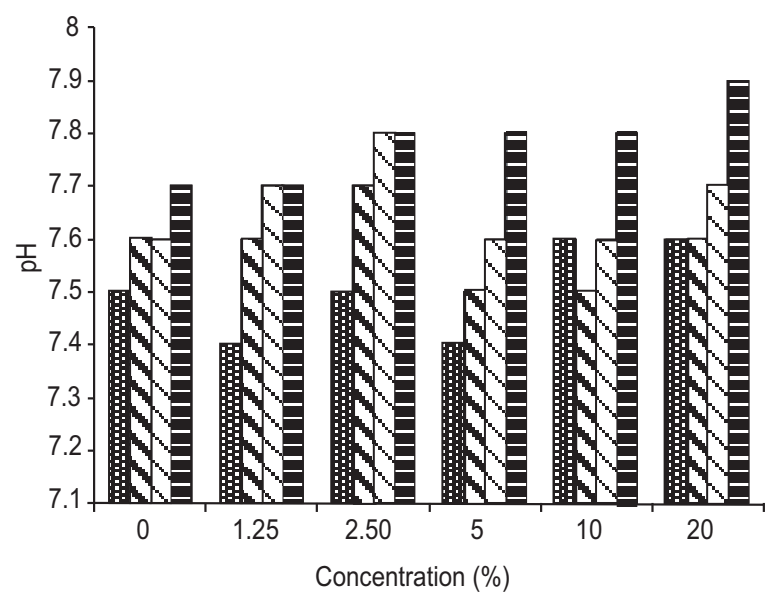

眀 24 Hour 48 Hour $\bigcirc 72$ Hour E96 Hour

Fig. 2. $\mathrm{pH}$ changes in the test solutions during the acute toxicity in C. gariepinus.

Also, at the end of $96 \mathrm{~h}$ toxicity testing, the mean temperature values of the exposure water are shown in Fig. 3. The results showed that the least temperature value $\left(23^{\circ} \mathrm{C}\right.$ ) was recorded in the control tank (without WSF).

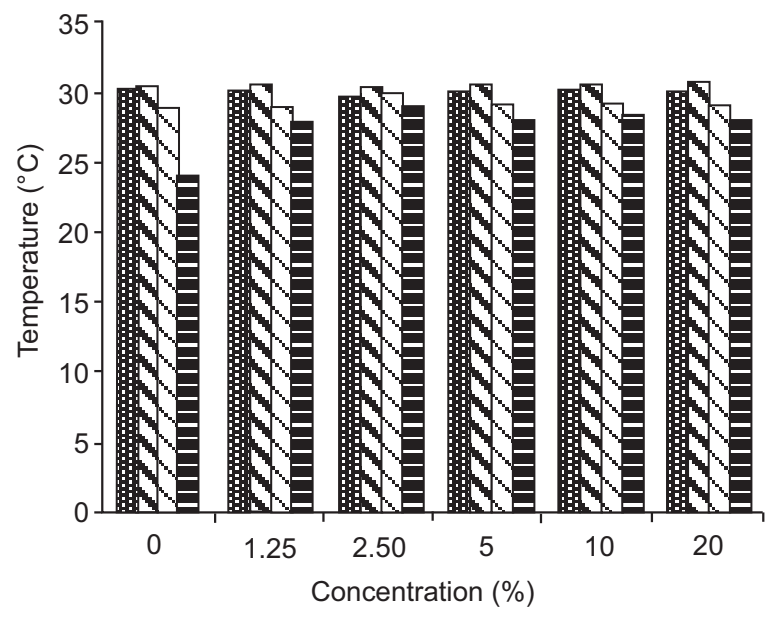

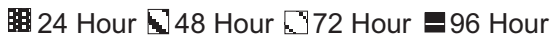

Fig. 3. Temperature changes in test solutions during the acute toxicity in $C$. gariepinus. 
The values obtained for the WSF of crude oil and control were further compared with Federal Environmental Protection Agency (FEPA, 1991) standards of water quality for sustenance of aquatic life (Horsfall and Spiff, 1998) (Table 3).

Table 3. Physicochemical parameters of WSF and control compared with FEPA

\begin{tabular}{llll}
\hline \hline Parameters & WSF & Control & FEPA(NESREA limits) \\
\hline $\begin{array}{l}\text { Temperature } \\
\left({ }^{\circ} \mathrm{C}\right)\end{array}$ & 29 & 28 & 30 \\
$\mathrm{pH}$ & 7.59 & 7.58 & $6.5-8.5$ \\
$\begin{array}{l}\text { Dissolved } \\
\text { oxygen }(\mathrm{mg} / \mathrm{L})\end{array}$ & 5.3 & 6.3 & $6.0-8.0$ \\
\hline \hline
\end{tabular}

The results of the study have shown that the water soluble fractions (WSF) of the Escravos blend elicited mortality in frys of C.gariepinus as low as $1.25 \%$ with a median lethal dose $\mathrm{LC}_{50}$ of $2.84 \%$. Even the weakest concentration of WSF, however, caused significantly, higher mortality than that caused by controls (Busdosh, 1981). This value can be considered as moderately toxic based on USEPA standards (USEPA, 1994). This toxic effect could be attributed to the constituents in water soluble fraction such as polycyclic aromatic hydrocarbon (PAH) (Eisler, 1987; Stegman et al., 1982; 1981). This is in agreement with the report of Brown and co-workers (Brown et al., 1983) indicated uptake of PAHs and associated declines in condition factor (CF), reproductive output, and other disease conditions in mussels and clams sampled. Meador et al. (2006) concluded that exposure levels were comparable to those causing adverse changes in growth and metabolism in feeding studies with PAHs.

It has been reported that eggs and young stages of fishes are especially vulnerable to the deleterious effects of toxic constituents in water bodies. Capuzzor and Lancaster (1981) investigated early embryonic and larval stages of fish and observed extreme sensitivity of these life forms to petroleum hydrocarbon. Kulnhold (1969) also reported the toxic effects of water extracts to herring eggs. There are indications that the pollutants have a retarding effect on the moulting process (Katz, 1973). Furthermore, the lethality observed could be adduced to stress conditions experienced as a result of the depletion of dissolved oxygen, which is similar to earlier studies by Dede and Kaglo (2001).
Immunosuppressive effects have also been found in salmon exposed to similar concentrations of PAHs in combination with other immunosuppressive contaminants such as PCBs (Arkoosh and Collier, 2002; Arkoosh et al. 2001). It could be speculated that the susceptibility of these early life forms to the toxicants (WSF of crude oil) may be related to the poor development of the xenobiotic metabolising enzymes of the early life forms. The mortality caused by WSF occurrs in a short time due to direct toxic effects of the WSF (Busdosh, 1981). Atema and Stein (1974) reported a reduction in crustacean feeding upon exposure to the water accommodated oil and WSF is a component. This was similar to that repor-ted by Wells and Spraque (1976). Exposure of oil may result in suppression of the desire to feed, or possibly because the animals were too weak or ill to eat, Busdosh (1981) reported that animals are interested in food, but have difficulty in recognizing it.

Conclusively, this study has shown that the exposure of C. gariepinus frys to even low concentrations (1.25\%) of water soluble fraction can induce toxicity effects as the study revealed the water soluble fraction caused mortality at increasing concentrations. Anderson et al. (1974) have pointed out that spills in quiet waters may allow the WSF to accumulate, as this fraction is not carried off as it leaches from the oil stick.

Considering the economic importance of fish as sources of food and income earning, indiscriminate release of crude oil mostly through spills should be controlled through proper monitoring and these findings could be valuable in "risk assessment" following crude oil spillage in water bodies.

\section{References}

Afolabi, O.A., Adeyemi, S.A., Imevbore, A.M.A. 1985. Studies on toxicity of some Nigerian crude oils to some aquatic organisms. In: Proceedings of International Seminar on the Petroleum Industry and the Nigerian Environment, pp. 269-272, Federal Ministry of Works and Housing, Kaduna, Nigeria.

Allen, P. 1995. Accumulation profiles of lead and cadmium in the edible tissues of Oreochromis aureus during acute exposure. Journal of Fish Biology, 47: 559-568.

Anderson, J.W. 1977. Responses of sublethal levels of petroleum hydrocarbons; Are they sensitive indicators and do they correlate with tissue contaminant. 
In: Fate and Effects of Petroleum Hydrocarbon, in Marine Organisms and Ecosystems, D. A. Wolfe (ed.), pp. 95-114, Perganon Press, New York, USA.

Anderson, J.W., Neff, J.M., Cox, B.A., Tatem, H.E., Hightower, G.M. 1974. Characteristics of dispersion and water soluble extracts of crude and refined oils and their toxicity to estuarine crustaceans and fish. Marine Biology, 27: 75-78.

APHA, 1992. Standards Methods for Examination of Water and Wastewater, $18^{\text {th }}$ edition, American Public Health Association, Washington, DC., USA.

Arkoosh, M.R., Collier, T.K. 2002. Ecological risk assessment paradigm for salmon: Analyzing immune function to evaluate risk. Human and Ecological Risk Assessment, 8: 265-276.

Arkoosh, M.R., Casillas, E., Clemons, E., Huffman, P., Kagley, A.N., Collier, T., Stein, J.E. 2001. Increased susceptibility of juvenile chinook salmon to vibriosis after exposure to chlorinated and aromatic compounds found in contaminated urban estuaries. Journal of Aquatic Animal Health, 13: 257-268.

Atema, J., Stein, L. 1974. Effects of crude oils on the feeding behavior of lobster Homarus americanus. Environmental Pollution, 6: 77-86.

Brown, D.A., Thompson, K.A., Heath, W.A., Erickson, P.E., Cretney, W.J., Wong, C.S. 1983. Histopathological evaluation of bivalves from Kitimat ArmDouglas Channel and Alberni Inlet, British Columbia. Canadian Technical Report of Hydrography and Ocean Science, 18: 196-218.

Busdosh, M. 1981. Long-term effects of the water soluble fraction of Prudhoe by crude oil on survival, movement and food search success of artic amphipod Boeckosimus (=Onisimus) affinis. Marine Environmental Research, 5: 167-180.

Capuzzo, J.M., Lancaster, B.A. 1981. Physiological effects of petroleum hydrocarbons on larvae of the American lobster (Homarus americanus): hydrocarbon accumulation and interphase with lipid Metabolism. In: Biological Monitoring of Marine Pollutants, J. A. V. Calabrese, F. P. Thurberg and W. B. Vernberg (eds.), pp. 477-499, Academic Press, New York, USA.

Dede, E.B., Kaglo, H.O. 2001. Aqua-toxicological effects of water soluble fraction (WSF) of diesel fuel on Oreochromis niloticus fingerlings. Journal of Applied Sciences and Environmental Management, 5: 93-96.

Ekweozor, I.K.E. 1989. A review of the effect of oil pollution in west African Environment. Discovery and Innovation, 1: 27-37.

Elisler, R. 1987. Polycyclic aromatic hydrocarbon hazards to fish, wildlife and invertibrates: a synoptic review. Contaminant Hazard Reviews Report No. 11, Biological Report 85 (1.11), U.S. Department of the Interior, Fish and Wildlife Service, Laurel, MD, USA.

Epstein, P.R., Selber, J. 2002. Oil: A Life Cycle Analysis of Its Health and Environmental Impact, 73 pp., The Center for Health and Global Environment, Harvard Medical School, Boston, Mass 02115, USA.

FEPA, 1991. Guidelines and Standards for Environmental Pollution Control in Nigeria, 238 pp., The Federal Environmental Protection Agency, Nigeria.

Horsfall, M., Spiff, A.I. 1998. Principles of Environmental Chemistry, pp. 112-119, Metropolis Ltd., Port-Harcourt, Nigeria.

Hufford, G.L. 1971. The Biological Response to Oil in The Marine Environment, Project No. 714141/003, US Coast Guard, Washington, DC., USA.

Katz, L.M. 1973. The effects of water soluble fraction crude oil on larvae of the decapod crustacean Neopanope texana (Sayi). Environmental Pollution, 5: 199-204.

Kunhold, W.W. 1969. Influence of water soluble compounds of crude oils and their fractions on the ontogenetic development of herring fry, Clupea herengus. Berdt Dtsch Wiss. Komm. Mecresforsch, 20: 165171.

Lee, K., Nedwed, T., Prince. R.C. 2011. Lab tests on the biodegradation rates of chemically dispersed oil must consider natural dilution. In: Proceedings of The International Oil Spill Conference (IOSC 2011), 12 pp., American Petroleum Institute, Portland, Oregon, Washington, DC., USA.

Meador, J.P., Sommers, F.C., Ylitalo, G.M., Sloan, C.A. 2006. Altered growth and physiological responses in juvenile Chinook salmon (Oncorhynchus tshawytscha) from dietary exposure to polycyclic aromatic hydrocarbons (PAHs). Canadian Journal of Fisheries and Aquatic Sciences, 63: 2364-2376.

Mohammad, A. 2005. Toxicity of water-soluble fractions of four fuels for Metamysidopsis insularis, an indigenous tropical mysid species. Environmental Monitoring and Assessment, 104: 37-44.

Murray, D.A., Lockhart, W.L., Webster, G.R.B. 1984. Analysis of the water-soluble fraction of crude oils and petroleum products by gas chromatography. 
Oil and Petrochemical Pollution, 2: 14-19.

Ojediran, B., Ndibe, J. 2005. Oil Spill Management. SPDC and the Environment, 123 pp., (unpublished).

Ololade, I.A., Oginni, O. 2010. Toxic stress and hematological effects of nickel on African catfish, Clarias gariepinus, fingerlings. Journal of Environmental Chemistry and Ecotoxicology, 2: 014019.

Rose, K.A., Cowan, J.H., Houde, E.D., Coutant, C.C. 1993. Individual based modeling of environmental quality effects on early life stages of fishes. A case study using striped bass. American Fisheries Society Symposium, 14: 125-145.

Sprague, J.B. 1973. The ABC's of pollutant bioassay using fish. In: Biological Methods for the Assessment of Water Quality, J. Carins and K. L. Dickson (eds.), American Society for Testing and Material, Philadephia, USA.

Svoboda, M. 2001. Stress in fishes. A review. Bulletin of Research Institute of Fish Culture and Hydrobiology Vodnany, 37: 169-191.

Stegeman, J.J., Shopeck, T.R., Whilly, W.G. 1982. Bioactivation of polynuclear aromatic hydrocarbons to cytotoxic and mutagenic products by marine fish. In: Carcinogenic Polynuclear Aromatic Hydrocarbons in the Marine Environment, N. Richards and B. L. Jackson (eds.), pp. 201-211, EPA 600/982-013, U.S. Environmental Protection Agency, Washington, D.C., USA.

Stegeman, J. 1981. Polynuclear aromatic hydrocarbons and their metabolism in the marine environment. In: Polycyclic Hydrocarbons and Cancer, H.V. Gelboin and P. O. Ts'o (eds.), vol. 3, pp. 1-160, Academic Press, New York, USA.

USEPA, 1994. 96-hour toxicity test using larval fathead minnows (Pimphales promelas), Compendium of ERT Standard Operating Protocols, pp. 80, Office of Solid Waste and Emergency Response, U.S. Environmental Protection Agency, New York, USA.

Well, P.G., Spraque, J.B. 1976. Effects of crude oil on American lobster Homarus americanus larvae in the laboratory. Journal of Fish Research Board and Canada, 33: 1604-1614.

Witeska, M. 2003. The effects of metals ( $\mathrm{Pb}, \mathrm{Cu}, \mathrm{Cd}$, and $\mathrm{Zn}$ ) on hematological parameters and blood cell morphology of common carp. Rozprawa naukowa nr 72, Wydawnictwo Akademii Podlaskiej Siedlce (In polish). 